\title{
FUNKCJONALNE TYPY SUBSTYTUTÓW W STRUKTURZE OKAZJONALNYCH INNOWACJI FRAZEOLOGICZNYCH: INTERPRETACJA Z UWZGLECDNIENIEM ASPEKTU GLOTTODYDAKTYCZNEGO
}

\begin{abstract}
Słowa kluczowe: frazeologizm, norma frazeologiczna, innowacja frazeologiczna, substytut, znajomość frazeologii, nauczanie frazeologii

Streszczenie. Artykuł poświęcony jest badaniu frazeologicznych innowacji wymieniających w tekstach współczesnej prozy polskiej (36 utworów autorstwa 10 współczesnych pisarzy polskich). Innowacje rozpatrywane są w dwóch płaszczyznach: strukturalno-semantycznej i funkcjonalno-pragmatycznej. Wydzielono 7 typów substytutów ze względu na funkcje pełnione przez nie w strukturze innowacji. Ustalono stopień wpływu przekształcenia formalnego na znaczenie frazeologizmu z uwzględnieniem trzech składników semantyki frazeologicznej - sygnifikacyjnego, desygnacyjnego i konotacyjnego. Opisano ewentualne sposoby wykorzystania tekstów zawierających innowacje wymieniające na zajęciach z frazeologii i języka polskiego jako obcego ze studentami polonistyki lwowskiej.
\end{abstract}

Modyfikowanie płaszczyzny leksykalnej związku frazeologicznego (dalej - ZF) polegające na zastąpieniu członu przez inny wyraz - substytut - jest jednym $\mathrm{z}$ najczęstszych zabiegów innowacyjnych stosowanych wobec frazeologizmów ${ }^{1} \mathrm{w}$ tekstach. Dowodem tego są liczne prace naukowe o innowacjach

*yuliia.stefanyshyn@Inu.edu.ua, Lwowski Uniwersytet Narodowy imienia Iwana Franki, Wydział Filologiczny, Katedra Filologii Polskiej, ul. Uniwersytecka 1, 79-000 Lwów.

${ }^{1} \mathrm{Za}$ jednostkę frazeologiczną uznaję ustabilizowane, odtwarzane w całości oraz ekspresywnie nacechowane połączenie wyrazowe, którego znaczenie nie jest sumą znaczeń elementów składowych. 
frazeologicznych ${ }^{2}$ w literaturze pięknej i publicystyce (np. Bąba 2009, Pajdzińska 1993, Liberek 1998, Dziamska-Lenart 2004, Ignatowicz-Skowrońska 2008, Tret'âkova 2011, Horoz 2008, Stefanišin 2016). Celem wymiany ustalonego elementu ZF na okazjonalny zazwyczaj jest wzmocnienie ekspresji wypowiedzi lub bardziej trafne oddanie zamierzonej treści. Zdarzają się jednak przekształcenia niezamierzone, a zatem nieuzasadnione, będące wynikiem niewystarczalnej znajomości obowiązującej tradycji.

Niniejszy artykuł poświęcony jest opisowi i interpretacji frazeologicznych innowacji wymieniających w tekstach współczesnej prozy polskiej, a także sposobom wykorzystania cytatów zawierających ww. innowacje na zajęciach z frazeologii i języka polskiego jako obcego ze studentami polonistyki lwowskiej. Kompetencja językowa ukraińskich studentów-polonistów w zakresie polskiej frazeologii konwencjonalnej już była przedmiotem badań naukowych. Analizie glottodydaktycznej poddawano m.in. frazeologię animalistyczną (Sahata 2013), temporalną, (Nikołajczuk 2013), biblijną (Krawczuk, Nikołajczuk 2017). Kilka prac poświęcono możliwości wykorzystania frazeologii polskich tekstów literackich - zarówno tej, zgodnej z normą, jak i innowacyjnej - na zajęciach z języka (Dilna 2008, 2011), jednak próba analizy walorów glottodydaktycznych innowacji wymieniających podejmowana jest po raz pierwszy.

Materiał badawczy to 200 innowacji wymieniających wyekscerpowanych z 36 utworów 10 pisarzy i pisarek polskich ${ }^{3}$, których dzieła obfitują w różnorodne strukturalno-semantyczne przekształcenia ustalonych połączeń wyrazowych. Fakt odstępstwa od normy ustalam poprzez zestawienie form frazeologizmów użytych w kontekstach $\mathrm{z}$ ich wersją kodyfikowaną w polskich słownikach ogólnych i frazeologicznych, w tym w ISJP, WSJP, WKS, WSFJP, SFPWN, SFJPPWNZP (objaśnienia skrótów słowników i utworów podaję przed bibliografią). Z kolei pomocą w odnalezieniu pomysłów na wykorzystanie zdobytego materiału w celach dydaktycznych służą dane specjalnie sporządzonej ankiety. 45 respondentów (studentów I-IV roku studiów licencjackich i I roku studiów magisterskich) wykonywało zadanie polegające na odtworzeniu konwencjonalnych form frazeologizmów podanych w kontekście w postaci zmodyfikowanej, a mianowicie z wymienionym członem/członami, oraz zdefiniowaniu ich znaczeń.

Klasyfikując odnalezione w tekstach innowacje wymieniające opieram się na kryterium funkcjonalnym. Ze względu na wpływ nowo wprowadzonego wyrazu na strukturę semantyczną ZF wyróżniam 7 typów substytutów, a mianowicie

${ }^{2}$ Terminem „innowacja frazeologiczna” określam wszelkie odstępstwa (świadome i nieświadome) od normy frazeologicznej, która jest „zbiorem zaaprobowanych przez polską społeczność językową frazeologizmów oraz reguł określających sposoby realizacji ich tożsamości w tekstach” (Bąba 2009, s. 41).

${ }^{3}$ Zbadane zostały utwory J. Fabickiej, I. Sowy, D. Noszczyńskiej, D. Stec, D. Masłowskiej, I. Karpowicza, S. Schutego, T. Piątka, D. Odiji, M. Nahacza. 
substytuty o funkcji: 1) nasilenia znaczenia, 2) osłabienia znaczenia 3) konkretyzacji znaczenia, 4) zmiany zabarwienia emocjalnego i stylistycznego, 5) demetaforyzacji, 6) odświeżenia obrazowości, 7) eksplikacji znaczenia. Taki podział funkcjonalny w literaturze przedmiotu nie jest nowy, korzysta z niego np. rosyjska badaczka I. Tretiakowa w swojej rozprawie habilitacyjnej (Tret'âkova 2011, s. 27-30). Stopień i charakter wspomnianego wpływu modyfikacji na frazeologizm wyjściowy badam przez pryzmat teorii złożoności frazeologicznej semantyki, według której znaczenie ZF zawiera tzw. składnik sygnifikacyjny (podstawowa, ogólna treść), desygnacyjny (dodatkowe treści wywodzące się z konkretnej sytuacji związanej z desygnatem) i konotacyjny (zabarwienie ekspresywne, emocjonalne i stylistyczne). Przytoczone terminy określające trzy składniki znaczenia frazeologicznego utrwaliły się głównie w pracach frazeologów wschodniosłowiańskich ${ }^{4}$, aczkolwiek składniki desygnacyjne i konotacyjne (inaczej semy desygnacyjne i konotacyjne) są w dużej mierze uwzględnione przy określeniu znaczeń frazeologizmów w niektórych polskich słownikach, a mianowicie tych, w których podane są definicje kontekstowe, np. ISJP, WKS.

Innowacje frazeologiczne zawierające substytut o funkcji nasilenia znaczenia ZF są dość częstym zjawiskiem w tekstach badanych powieści. W strukturze takich ZF zamiast członu przewidzianego przez normę pojawia się jednostka leksykalna o podobnym znaczeniu charakteryzującym się jednak większą intensywnością. Innowacje tego typu powstają, na przykład, w wyniku zastąpienia leksemu zawierającego w semantycznej strukturze składnik kwantytatywny przez inny leksem ze składnikiem kwantytatywnym o większej wartości, jak oto w kontekście: Obshuga troi się i czworzy, by tak ważnym gościom, rozsiadającym się swobodnie $w$ fotelach, mito się dziato (Nh, s. 162), por. dwoić się i troić, 'być niezwykle czynnym; uwijać się' (SFPWNZP, s. 89). W wyniku przekształcenia podstawowy sem sygnifikacyjny w semantycznej strukturze ZF nie ulega zmianie, natomiast rośnie ekspresywność, a zatem zmienia się konotacja.

W przypadku substytucji metonimicznej totum pro parte nasilenie znaczenia ZF jest wynikiem zastępowania (nie koniecznie świadomego) tradycyjnego członu będącego nazwą części przez człon okazjonalny będący nazwą całości, np.: Niech no ja ja jeszcze raz na swojej drodze spotkam, to tak prześwięce, że ruski rok popamięta! - zapowiedziat groźnie (BMN, s. 175), por. popamiętać ruski miesiąc 'zapamiętać karę na długo, odczuć coś dotkliwie' (WSFPWNZP, s. 456). Na skutek wymiany członu nominalnego miesiac na element rok, oznaczający znacznie dłuższy okres czasu, struktura semantyczna frazeologizmu wzbogaca się o sem konotacyjny 'bardzo', a zatem innowacja przybiera znaczenie 'zapamiętać karę na bardzo długo, odczuć coś bardzo dotkliwie'. Podobny przykład mieści się w kontekście: Oczywiście, jeśli pan złamie nasza umowę, już nigdy pana nie obstużę. Nie będę maczal rakk w pańskiej śmierci (H, s. 75), por. maczać w czymś

${ }^{4}$ Zob. np. Teplâkov 2005, Kravčuk 2005, Krawczuk, Nikołajczuk 2017. 
palce 'brać udział, zwykle niejawnie, w jakiejś nieuczciwej sprawie, przyczyniać się do czegoś ocenianego negatywnie' (WSFPWNZP, s. 335). Stopień zaangażowania podmiotu w jakąś nieuczciwą sprawę rośnie wprost proporcjonalnie do zwiększenia powierzchni obiektu nazywanego przez człon nominalny frazeologizmu (por. palce - ręcę). Kodyfikowane znaczenie ZF wzbogaca się o sem konotacyjny 'aktywny' i przybiera postać 'brać aktywny udział, zwykle niejawnie, w jakiejś nieuczciwej sprawie'.

Skutkiem substytucji metonimicznej może być zarówno nasilenie, jak i osłabienie znaczenia $\mathbf{Z F}$. Wymiana metonimiczna pars pro toto polega na zastępowaniu tradycyjnego członu frazeologizmu będącego nazwą całości przez leksem nazywający część, np.: - Co tam dalej. Aha, dyskoteka: dam se uciońć durzy palóch lewej stopy, że zamknienta na cztery spósty ${ }^{5}$ (DMC, s. 110), por. ktoś da sobie głowe, rękę, łeb uciąć, że... 'ktoś jest całkowicie pewny, że..., twierdzi z całą pewnością, że...' (SFPWN, c. 56).

Osłabienie znaczenia ZF może również nastąpić w wyniku wymiany leksemu zawierającego w semantycznej strukturze składnik kwantytatywny na inny leksem ze składnikiem kwantytatywnym o mniejszej wartości, np.: Pramolan okazal się strzalem $w$ ósemke. Może nawet $w$ dziewiatke (SŚM, c. 44), por. strzat $w$ dziesiatke 'wyjątkowo udany pomysł' (WSFPWNZP, s. 518). Substytuty ósemka i dziewiątka, które zostały celowo użyte zamiast tradycyjnego członu dziesiątka będącego leksemem o większej wartości kwantytatywnej, osłabiają ustalone znaczenie frazeologizmu: sem 'wyjątkowo' jest eliminowany z semantycznej struktury ZF.

Pojawienie się substytutu o funkcji konkretyzującej w obrębie innowacji frazeologicznej wiąże się z potrzebą sprecyzowania, uszczegółowienia wypowiedzi, dodatkowego opisania osoby, przedmiotu, zjawiska lub sytuacji nazywanej przez frazeologizm, innymi słowy - z potrzebą udzielenia dodatkowych informacji o desygnacie. Struktura semantyczna ZF jest zatem uzupełniana o okazjonalne semy desygnacyjne, np.: A jak już przejmiemy kwas siarkowy, to pójdziemy pod szkołę, aby porozmawiać z chłopaczkiem i zlecić mu zadanie specjalne. Zadanie specjalne, z którego wróci w kajdankach. Ja nigdy nie rzucam gróźb na wiatr (DP, s. 27), por. nie rzucać stów na wiatr 'mówić, obiecywać coś w sposób odpowiedzialny, być słownym, dotrzymywać słowa' (WSFPWNZP, s. 610). W wyniku wymiany członu nominalnego zakres semu 'mówić, obiecywać' zawężono do 'grozić', z kolei implicytny sem konotacyjny 'coś pozytywnego' (obieca się przecież coś dobrego) eliminowano, a nowe znaczenie ZF przybrało konotację negatywną.

Nazwę desygnatu zamiast tradycyjnego członu ZF zawiera innowacja wymieniająca w kontekście: Wreszcie pora przejrzeć albumy, oddzielając wartościo-

${ }^{5} \mathrm{~W}$ cytacie zachowana zastała pisownia oryginalna. Autorka świadomie ignoruje zasady normy ortograficznej języka polskiego w celach stylizacyjnych. 
we fotografie od plew bezlitośnie obnażajacych obfite kalafiory na udach matki lub plebejskie rozrywki ojca (DMC, s. 80), por. oddzielić ziarno od plew 'oddzielić to, co dobre, od tego, co złe, oddzielić dobrych od złych, odrzucić to, co złe' (WSFPWNZP, s. 688). Wynikiem przekształcenia formy ZF jest konkretyzacja desygnatu: przedmioty, które zgodnie z kontekstem są dzielone na grupy według kryterium dobry - zty, to zdjęcia.

Osobliwością innowacji frazeologicznych zawierających substytut o funkcji konkretyzującej jest to, że wiele z nich powstaje na podstawie przysłów, np.: - Lekcja nie zając, dzięki Bogu. Pośle kogoś, żeby tymczasem pania zastapit (B, c. 244), por. praca/robota nie zając, nie ucieknie 'wymówka od pracy lub zachęta do odpoczynku, poleniuchowania' (WSFPWNZP, s. 665); Podziękowałam pięknie i opuścilam urząd przekonana, że przez informacje przemawiato po prostu skrzywienie zawodowe. No bo przecież każdy normalny człowiek mógt sobie chodzić w garniturze bez krawata dlatego, że lubit, a nie dlatego, że nie mógt. - A, tam - westchnętam. - Jedna informacja jeszcze wiosny nie czyni (HN, c. 193), por. jedna jaskółka [jeszcze] wiosny nie czyni 'jedno - zwykle pozytywne - wydarzanie nie świadczy o tym, że oczekiwane zmiany już nadchodzą' (WSJP), 'nie należy wyciągać zbyt pochopnych wniosków z jednego wydarzenia' (WSFPWNZP, s. 149); Telefon odbit się od ściany i rykoszetujac, uderzyt Artura za lewym uchem.- Auć!!! - syknat. Jeden do jednego - zatriumfowała Anna. - Oko za oko. Guz za guz (C 85), por. oko za oko, zab za zab 'zasada wymierzania sprawiedliwości w sposób bezwzględny, okrutny, odpłacenie złem za zło' (WSFPWNZP, s. 322); Znajomi z wozu, koniom lizej. Można sobie porzadnie purknać w sklepie bez utraty twarzy (CwN, c. 26), por. baba z wozu, koniom lizej 'o sytuacji, w której pozbycie się kogoś lub czegoś przynosi ulgę' (WSFPWNZP, s. 9); Siadam na przystanku dziesiątki tylko dlatego, że młodzi nie zniszczyli ławki. Co prawda bez zadaszenia, ale lepsza lawka pod dupa, niż gotab na dachu (Nh, c. 61), por. lepszy wróbel w garści / w ręku niż gołąb na dachu 'warto jest dysponować czymkolwiek, nawet jeśli nie zaspokaja to całkowicie naszych oczekiwań' (WSFPWNZP, s. 211): - Nie miała baba ktopotu, to sie do Filmówki dostata (TO, c. 22), por. nie miała baba kłopotu, kupiła sobie prosię 'o sytuacji, w której ktoś sam przysporzył sobie kłopotów’ (WSFPWNZP, c. 9) itd.

Pojawienie się w obrębie ZF substytutu o funkcji zmiany zabarwienia emocjalnego i stylistycznego powoduje przeobrażenia struktury semantycznej frazeologizmu na poziomie konotacji. Wymiany leksemów neutralnych na książkowe, podniosłe (tzw. substytucje melioryzacyjne) zdarzają się w badanych utworach bardzo rzadko, zdecydowanie częściej autorzy udają się do upotocznienia frazeologizmów, obniżenia ich wartości stylistycznej, pejoratywizacji. Najbardziej podatne na takie zmiany są frazeologizmy somatyczne, w których strukturze zamiast nazw części ciała człowieka pojawiają się nazwy części ciała zwierząt, np.: Postanowiłam pomodlić się po apelu za jego duszę, ale jakoś mi to umknęto. 
Klepałam więc na chybcika wieczne odpoczynki w drodze do szkoły, co było o tyle trudne, że Zuzi nie zamykala się paszcza (HN, c. 180), por. пор. usta się komuś nie zamykaja, gęba/buzia się komuś nie zamyka 'ktoś mówi bez przerwy' (WSFPWNZP, c. 669), paszcza 1. 'duży i groźnie wyglądający otwór w przedniej części głowy niektórych zwierząt, zwłaszcza drapieżnych, służący im do pobierania pokarmu', 2. 'usta lub twarz człowieka, słowo potoczne i nieuprzejme' (ISJP, t. 2, s. 32);-Zamordowano mi matkę. Musze ja pochować. To się zdarza-dodała, próbujac udobruchać starego - tylko raz. Profesor zamilkt. A to moja stara miata wyciagnaç te swoje zdeformowane płetwy pomyślat. Świat nie jest sprawiedliwy (C, s. 190), пор. wyciagnać nogi, kopyta 'umrzeć' (WSFPWNZP, s. 638), pletwy 'cienkie błoniaste narządy u ryb kształtem przypominające małe skrzydła, służące im do poruszania się w wodzie i utrzymywania ciała $\mathrm{w}$ określonej pozycji' (ISJP, t. 2, s. 91); Pokolenie petne nieuzasadnionych pretensji i niezdolne zatroszczyć się o własne sprawy. Ci ludzie, ustyszat zawstydzony Wiesiek, wyciagaja tape po nieswoje (DMC, s. 141), пор. wyciagać rękę 'chcieć sobie coś przywłaszczyć' (WSFPWNZP, s. 638), łapa 1. 'noga zwierzęcia, nie zakończona kopytem', 2. 'ludzka ręka, słowo potoczne i ekspresywne' (ISJP, t. 1, s. 788); - Dobrze, to ja wysiadę. Dziękuje za pomoc. - Lapka oddaje monety. - Ty, nie bądź glupia - podpowiada szeptem sprytny. - Żaden kanar nie wyściubi dzioba w taki mróz. - A nawet jeśli, to kucniesz i nie ma szans, żeby cię wytuskat - dodaje inny (DMC, s. 184), por. nie wyściubiać, nie wyściubić skądś nosa 'nie opuszczać, nie opuścić jakiegoś miejsca, nie wychodzić, nie wyjść poza jakieś pomieszczenie, poza jakiś teren' (WSFPWNZP, s. 290), dziób 1. 'przednia twarda i wydłużona część głowy ptaka, często zwężająca się ku końcowi, służąca przede wszystkim do chwytania pokarmu', 2. 'twarz lub same usta, słowo potoczne i nieuprzejme' (ISJP, t. 1, s. 359). Deprecjonujący charakter wypowiedzi w tekstach współczesnej prozy już dawno nie jest zjawiskiem zaskakującym, a zatem pojawienie się negatywnie konotowanych znaków językowych w strukturze ZF jako elementów będących tworzywem takiej literatury jest dość naturalne.

Subsytuty z funkcją demetafotyzacji odwołują się do dosłownych znaczeń elementów ZF powodując jego podwójne odczytanie - jako frazeologizmu i jako swobodnego połączenia wyrazowego. Żeby to było możliwe, w kontekście powinny znaleźć się aktualizatory dosłownego i metaforycznego znaczenia ZF. Taka innowacja najczęściej przybiera postać okazjonalnej autorskiej wersji składu leksykalnego frazeologizmu z komentarzem objaśniającym pojawienie się w jego obrębie nieoczekiwanego substytutu w miejscu elementu przewidzianego przez normę, np.: Hela zaniosła się perlistym śmiechem, co wytracito mnie z równowagi, ale zaraz zebratem się w sobie, by oznajmić hiobowa wieść: - Chyba mnie nie dopuszcza do egzaminów, bo oblatem wszystkie testy próbne. Ojciec zacząt wyrywać sobie wlosy z klaty (bo na glowie już nie ma), a babcia zarządzita poszukiwanie sztucznej szczęki, która wypadta jej pod czas radosnych 
podskoków (ŚT, s. 72), пор. wyrywać (sobie) włosy z głowy 'bardzo rozpaczać, czasem czynią przy tym gest sugerujący wyrywanie sobie włosów' (WSFPWNZP, s. 623). U podstaw frazeologizmu konwencjonalnego leży połączenie wyrazowe oznaczające czynność realną, możliwą do wykonania. To umożliwia dosłowne odczytanie ZF w odpowiednich warunkach, które w powyższym kontekście są realizowane poprzez wymianę członu nominalnego i dodanie ironicznego komentarza. Znaczenie frazeologiczne zostaje odsunięte na plan dalszy.

Jeśli w poprzednim przykładzie dosłowne znaczenie ZF zostało w pełni przywrócone, to w kolejnym przykładzie możliwa jest wyłącznie jego częściowa aktualizacja ze względu na irrealność wewnętrznej formy frazeologizmu: Lokal okazat się bardzo europejski i bardzo luksusowy. Portier i te sprawy. Jablkowa mtodziez (bo nie bananowa, o banany $w$ Etiopii nie trudno, za to o jabtka - owszem), elegancko odziana, dyskretnie ozłocona, grała $w$ bilard (NKC, s. 170), por. bananowa młodziez 'rozpieszczona nadmiernym dostatkiem młodzież, prowadząca beztroski tryb życia, korzystająca z pozycji materialnej i społecznej swoich rodziców' (WSFPWNZP, s. 11). Poprzez wstawienie w strukturę ZF przymiotnika jabłkowa, semantyczne nawiązującego do pierwowzoru $b a$ nanowa, oraz dodanie odpowiedniego komentarza autorowi udaje się osiągnąć cudowny efekt ironiczny połączony z udanym dostosowaniem frazeologizmu do realiów opisywanych w utworze.

Wymiana elementu frazeologizmu na substytut o funkcji odświeżenia obrazowości ZF jest zabiegiem nieuwarunkowanym sytuacyjnie oraz nie powodującym zmian w strukturze semantycznej, służącym jedynie uwspółcześnieniu nieco zatartego obrazu ZF, np.: - Dziasiaj to taki jeden z drugim szef z bożej łaski, to by chciat jeździć na tobie jak na burej szkapie. Cały problem w tym, że ja nie pozwole soba poniewierać (BMN, s. 28), por. jeździć na kimś jak na łysej kobyle 'lekceważąco kogoś traktować, poniewierać kimś, wykorzystywać kogoś' (WSFPWNZP, s. 172); - Nic z tego nie rozumiem - pokręciłam głowa. - Same skróty. - Przecież to proste jak kilo sznurka w kieszeni - zirytowała się Jolka (SŚM, s. 116), por. coś jest proste jak drut 'o czymś, co jest jasne, zrozumiałe, nie wymagające wyjaśnien' (WSFPWNZP, s. 83); - Teraz naprawdę zemdleję - szepnęła Maria i na poparcie swoich stów zrobiła się blada niczym maka kartoflana (CW, s. 106); Kiedy wrócił, byt bialy jak amfetamina (SiIP, s. 144), por. biały, blady jak ściana, jak papier, jak chusta, jak płótno, jak kreda, jak śmierć 'ktoś jest bardzo blady' (WSFPWNZP, s. 18). Nowe składniki w utrwalonych połączenia wyrazowych zależą od pomysłowości autora.

Substytuty z funkcją eksplikacji znaczenia $\mathbf{Z F}$ to takie nowo wprowadzone leksemy, które kopiują semy znaczenia frazeologicznego powodując redundancję, która z punktu widzenia normy jest oceniana raczej negatywnie - jako zjawisko zbędne i nieuzasadnione, np.: - Nie tak, Miguel, nie tak - w ciemności rozlegt się głos Chauvina. - Co się z toba dzieje? Miguel nic nie odpowiedziat. Potem 
syknat przez zęby: - Kiedy tak robisz, zabierasz mi dignidad (BW, s. 115), por. mówić, powiedzieć przez zęby 'mówić, powiedzieć coś wolno, cicho i najczęściej ze złością, oddzielając wyrazy od siebie' (WSFPWNZP, s. 680). W strukturze innowacji syknać przez zęby podstawowy człon werbalny syknać jest substytutem użytym zamiast tradycyjnego komponentu powiedzieć. Zgodnie z danymi ISJP jedno ze znaczeń leksemu syknać jest następujące: 'Jeśli ktoś syknął, to powiedział to przez zaciśnięte zęby, często ze złością' (ISJP, t. 2, s. 724). Tak więc struktura semantyczna nowego komponentu powtarza semy 'przez zęby', 'ze złością', zawarte w znaczeniu ZF, a zatem wprowadzenie owego leksemu zamiast neutralnego powiedzieć powoduje niepotrzebne nawarstwianie semantycznie tożsamych elementów. Użycie substytutów tego typu można częściowo uzasadnić z pragmatycznego punktu widzenia - jako takie, które ułatwiają zrozumienie metafory będącej podstawą ZF.

Wykorzystanie zgromadzonego i częściowo przedstawionego wyżej materiału frazeologicznego na zajęciach z ukraińskojęzycznymi studentami polonistyki wydaje się dobrym pomysłem. Frazeologizmy bowiem pojawiają się na wszystkich poziomach nauczania polszczyzny, ich opanowanie jest ważnym elementem zajęć poświęconych kształceniu sprawności leksykalno-komunikacyjnych. One wzbogacają słownictwo, rozwijają kompetencję kulturową, są narzędziem do poznania językowego obrazu świata. Zdolność do aktywnego posługiwania się frazeologizmami oraz umiejętność odczytania wszystkich składników znaczenia ZF rozwijana jest nie tylko na zajęciach z praktycznej polszczyzny, ale również w ramach obowiązkowego kursu programowego poświęconego frazeologii polskiej (łącznie 90 godzin: 32 godz. wykładów i 58 godz. pracy samodzielnej), na który studenci uczęszczają $\mathrm{w}$ pierwszym semestrze drugiego roku studiów. W trakcie zajęć zapoznają się z podstawowymi i peryferyjnymi cechami ZF, szerokim i wąskim rozumieniem frazeologii, rozwojem tej dyscypliny językoznawczej w Polsce, kierunkami badań frazeologicznych, klasyfikacjami frazeologizmów na podstawie różnych kryteriów, różnicami między frazeologią funkcjonalną a systemową, teorią trzech składników znaczenia frazeologicznego, specyfiką przedstawiania znaczeń ZF w różnych słownikach, pojęciem normy, wariantywności, innowacji i błędu frazeologicznego, rodzajami innowacji frazeologicznych oraz rolą elektronicznych korpusów tekstów w badaniach współczesnej frazeologii polskiej.

Innowacje frazeologiczne zawierające substytuty różnych typów są skutecznym narzędziem wspomagającym utrwalenie kilku z wyżej wymienionych aspektów frazeologii jako dyscypliny naukowej. Chodzi m.in. o teorię sygnifikacyjnego, desygnacyjnego i konotacyjnego składnika semantyki frazeologicznej. Substytuty o funkcji nasilenia i osłabienia znaczenia, jak również substytuty zmieniające zabarwienie stylistyczne ZF służą pomocą przy wyjaśnieniu studentom, co to jest konotacja, jakie jest jej miejsce w strukturze semantycznej frazeologizmu. Z kolei 
za pomocą innowacji zawierających substytuty konkretyzujące uczącym się można zademonstrować różnicę między sygnifikacyjnym a desygnacyjnym składnikiem znaczenia ZF.

Substytuty o funkcji odświeżenia obrazu są przykładem okazjonalnej frazeotwórczości, której funkcjonalność warto rozważyć ze studentami, ewentualnie zainicjować dyskusję na temat jej celowości i omówić konkretne przykłady w kontekstach. Ocena przekształceń zawierających takie substytuty jest bowiem kwestią subiektywną, gdyż z jednej strony ich użycie można uzasadnić, biorąc pod uwagę fakt odnowienia zblakniętej obrazowości ZF, z drugiej zaś potępić jako niepotrzebne rozszerzenie granic wymienności członów frazeologizmu.

Innowacje z substytutami demetaforyzującymi zaopatrzone w komentarze autorskie demonstrują odstępstwa od normy frazeologicznej nie tylko w zakresie stabilności struktury ZF, ale również w zakresie zharmonizowania frazeologizmu $\mathrm{z}$ otoczeniem słownym. Studenci poznają więc, jakie istnieją zasady poprawnego posługiwania się frazeologizmami, co to jest kontekst minimalny i maksymalny oraz jakie warunki powinien on spełniać, żeby znaczenie metaforyczne ustabilizowanego połączenia wyrazowego zostało w pełni zrealizowane w kontekście. I odwrotnie: jakie elementy otoczenia słownego powodują, że omawiane innowacje wymieniające odczytywane są jak związki luźne, jakie cechy powinny przybierać owe „demetaforyzatory” i jakie efekty są osiągane dzięki nim w tekście w tym przypadku, jeśli są one chwytem zamierzonym. Z kolei odróżnienie modyfikacji uzasadnionych od niepożądanych, a nawet błędnych, wspomagają przykłady innowacji frazeologicznych zawierających substytuty, które niepotrzebnie eksplikują znaczenia kodyfikowanych pierwowzorów.

Obecność kursu frazeologii w programie edukacyjnym na polonistyce lwowskiej, jak również niepodważalny fakt podobieństwa między zasobami frazeologicznymi języka polskiego i ukraińskiego, przyczyniają się do tego, że ukraińscy studenci na ogół dobrze radzą sobie z frazeologią polską, w tym z rozpoznawaniem innowacji frazeologicznych w tekście. Potwierdzają to m.in. wyniki wspomnianej na początku artykułu ankiety, przeprowadzonej wśród studentów o różnym poziomie kompetencji językowej (13 z I, 18 z II, 6 z III, 4 z IV roku studiów licencjackich oraz $5 \mathrm{z}$ I roku studiów magisterskich ${ }^{6}$ ) z wykorzystaniem fragmentów utworów zawierających 27 innowacji wymieniających różnych typów. Studenci nieźle poradzili sobie $\mathrm{z}$ odtworzeniem konwencjonalnych form ZF, co jest odzwierciedlone w poniższej tabeli:

${ }^{6} 32$ respondentów (71 proc.) jest po kursie frazeologii. 
Tabela 1. Wyniki wykonania przez studentów polonistyki lwowskiej zadania polegajacego na odtworzeniu konwencjonalnych form ZF

\begin{tabular}{|c|c|c|c|c|}
\hline \multirow{2}{*}{ Innowacja wymieniająca } & \multirow{2}{*}{ Pierwowzór (kodyfikowany ZF) } & \multicolumn{3}{|c|}{ Odpowiedzi respondentów } \\
\hline & & $\mathbf{P}^{*}$ & $\mathbf{N}$ & B \\
\hline nie rzucać gróźb na wiatr & nie rzucać stów na wiatr & 41 & 0 & 4 \\
\hline znajomi z wozu, koniom lżej & baba z wozu, koniom lizej & 39 & 1 & 5 \\
\hline $\begin{array}{l}\text { nie miała baba kłopotu, to się do } \\
\text { filmówki dostała }\end{array}$ & $\begin{array}{l}\text { nie miała baba kłopotu, kupiła } \\
\text { sobie prosię }\end{array}$ & 38 & 0 & 12 \\
\hline strzat w ósemkę, dziewiątkę & strzat $w$ dziesiatke & 34 & 0 & 11 \\
\hline oko za oko, guz za guz & oko za oko, ząb za ząb & 34 & 2 & 9 \\
\hline zaglądać do kufla & zaglądać do kieliszka/butelki & 33 & 2 & 10 \\
\hline kuć nabywcę, póki goracy & kuć żelazo, póki gorące & 32 & 2 & 11 \\
\hline jedna informacja wiosny nie czyni & jedna jaskółka wiosny nie czyni & 30 & 4 & 11 \\
\hline mieć coś na końcu ozora & mieć coś na końcu języka & 28 & 0 & 17 \\
\hline troić się i czworzyć & dwoić się i troić & 27 & 0 & 18 \\
\hline $\begin{array}{l}\text { lepsza ławka pod dupa, niż gołąb } \\
\text { na dachu }\end{array}$ & $\begin{array}{l}\text { lepszy wróbel w garści, niż gołąb } \\
\text { na dachu }\end{array}$ & 26 & 2 & 17 \\
\hline $\begin{array}{l}\text { mieć serce miękkie niczym serek } \\
\text { homogenizowany }\end{array}$ & mieć serce miękkie jak wosk & 24 & 5 & 20 \\
\hline biaty jak amfetamina & $\begin{array}{l}\text { biały/blady jak ściana/papier/ } \\
\text { płótno/kreda/chusta/śmierć }\end{array}$ & 24 & 10 & 11 \\
\hline $\begin{array}{l}\text { ktoś da sobie uciać duży paluch } \\
\text { lewej stopy, że... }\end{array}$ & $\begin{array}{l}\text { ktoś da sobie rękę, głowę, teb } \\
\text { uciąć, że... }\end{array}$ & 21 & 5 & 19 \\
\hline popamiętać ruski rok & popamiętać ruski miesiąc & 21 & 11 & 13 \\
\hline słowo się rzekło, koniaczek u płota & słowo się rzekto, kobytka u płota & 21 & 3 & 21 \\
\hline poprzewracało się komuś $w$ dupie & poprzewracało się komuś w głowie & 19 & 4 & 22 \\
\hline $\begin{array}{l}\text { jeździć na kimś jak na burej } \\
\text { szkapie }\end{array}$ & jeździć na kimś jak na tysej kobyle & 19 & 4 & 22 \\
\hline żal ściska dupę & żal ściska serce & 19 & 12 & 14 \\
\hline maczać w czymś ręce & maczać $w$ czymś palce & 19 & 7 & 19 \\
\hline nie wyściubiać skądś dzioba & nie wyściubiać skądś nosa & 18 & 3 & 24 \\
\hline $\begin{array}{l}\text { bujać w górnej warstwie } \\
\text { stratosfery }\end{array}$ & bujaćw obłokach & 18 & 1 & 26 \\
\hline $\begin{array}{l}\text { oddzielić wartościowe fotografie } \\
\text { od plew }\end{array}$ & oddzielić ziarno od plew & 17 & 0 & 28 \\
\hline kino nie zajac, nie ucieknie & $\begin{array}{l}\text { praca/robota nie zajac, nie } \\
\text { ucieknie }\end{array}$ & 13 & 16 & 16 \\
\hline wyciagnać zdeformowane ptetwy & wyciagnać nogi/kopyta & 9 & 1 & 35 \\
\hline pędzić na złamanie karoserii & pędzić na złamanie karku & 8 & 4 & 33 \\
\hline $\begin{array}{l}\text { coś jest proste jak kilo sznurka } \\
\text { w kieszeni }\end{array}$ & coś jest proste jak drut & 7 & 16 & 22 \\
\hline
\end{tabular}

${ }^{*} \mathrm{P}$ - poprawna forma pierwowzoru, $\mathrm{N}$ - niepoprawna forma pierwowzoru, $\mathrm{B}$ - brak jakiejkolwiek odpowiedzi respondenta.

Źródło: opracowanie własne 
Wypowiedzi ankietowanych pomagają ustalić, jak najskuteczniej wykorzystać zgromadzony materiał frazeologiczny w celu dydaktycznym, na jakie aspekty należy zwrócić szczególną uwagę ucząc studentów ukraińskojęzycznych frazeologii języka polskiego od podstaw. Według uzyskanych danych, 13 z 27 ZF okazało się dość prostych do zidentyfikowania: tradycyjne formy 5 ZF poprawnie odtworzyło więcej niż 75 proc. respondentów, pozostałe 8 zgadło więcej niż 50 proc. uczestników ankietowania. Większość z tych frazeologizmów ma w języku ukraińskim aktywnie używane ekwiwalenty o bardzo podobnej formie i znaczeniu, co znacznie ułatwia studentom wykonanie zadania, np. baba z wozu, koniom lizej (por. баба з воза, коням / колесам легше), nie miała baba kłopotu, kupiła sobie prosię (por. не мала баба клопоту - купила порося), оko za oko, zab za zab (por. око за око, зуб за зуб), kис́ żelazo, póki gorące (por. кувати залізо, поки гаряче), јеdna jaskótka wiosny nie czyni (por. одна ластівка ще весни не робить), тіес́ соś nа końcu języka (por. щось крутиться на язииi), lepszy wróbel w garści, niż gołą na dachu (por. краще синиия в руках, ніж журавель у небi), zagladać do kielisz$k a$ (por. заглядати в чарку). Największa liczba niepoprawnych odpowiedzi w tej grupie dotyczy frazeologizmu biały/blady jak ściana/papier/płótno/kreda/chusta/ śmierć, który należało zidentyfikować (nie koniecznie z całym ciągiem wymiennych elementów, oczywiście) na podstawie innowacji biały jak amfetamina. Aż 7 respondentów podało wersję *biały jak śnieg kalkując z języka ukraińskiego utarte porównanie білий як сніг 'śnieżnobiały', które strukturalnie i semantycznie jest przybliżone wymienionego frazeologizmu polskiego, ale w swojej strukturze znaczeniowej posiada inny składnik desygnacyjny i na płaszczyźnie normy występuje w połączeniach z rzeczownikami nieosobowymi. Kontekst, w którym została użyta innowacja biały jak amfetamina, wyraźnie wskazuje na ,żywotność” desygnatu, ale nie wszystkim studentom udało się to zauważyć.

Drugą grupę stanowi 14 frazeologizmów, które okazały się trudniejsze do zidentyfikowania. Mniej niż połowie respondentów udało się poprawnie wymienić tradycyjne formy ZF ktoś da sobie rękę, glowę, teb uciać, że..., popamiętać ruski miesiac, słowo się rzekło, kobyłka u płota, poprzewracało się komuś w głowie, jeździć na kimś jak na tysej kobyle, żal ściska serce, maczać w czymś palce, nie wyściubiać skądś nosa, bujać w obłokach, oddzielić ziarno od plew, praca nie zajac, nie ucieknie, wyciagnać nogi/kopyta, pędzić na złamanie karku, coś jest proste jak drut. Przyczyny niskich liczb prawidłowych odpowiedzi dla poszczególnych frazeologizmów są różne. Tak, liderami w rubryce „brak jakiejkolwiek odpowiedzi" są utrwalone połączenia wyrazowe wyciagnać nogi/kopyta i pędzić na złamanie karku - aż 35 i 34 studentów odpowiednio nie rozpoznało tradycyjnych ZF w kontekstach zawierających innowacje wyciagnać zdeformowane płetwy, pędzić na złamanie karoserii. W przypadku pierwszego ZF podejrzewam, że wielu ankietowanych nie zrozumiało znaczenia substytutu płetwy (ukraiński odpowiednik tego wyrazu ласти brzmi zupełnie inaczej). Gdyby znali jego semantykę, bez 
trudu rozpoznaliby frazeologizm choćby dlatego, że w języku ukraińskim wyraz ласти również jest używany zamiast neutralnego ноги 'nogi' w wypowiedziach nacechowanych ekspresywnie, $\mathrm{z}$ kolei w zasobie frazeologicznym istnieje ZF витягнути ноги będący ekwiwalentem polskiego wyciagnąc nogi. W drugiej $\mathrm{z}$ wyżej wymienionych innowacji między substytutem karoseria i normatywnym członem kark nie ma powiązań semantycznych. Mimo to przypuszczam, że nieznajomość znaczenia substytutu i brak ekwiwalentu ZF w ukraińskim zasobie frazeologicznym przyczyniły się do problemów z identyfikacją frazeologizmu $p e ̨-$ dzić na złamanie karku w kontekście.

Jako błędne zostały zakwalifikowane odpowiedzi, w których respondenci: 1) zaznaczyli, że forma ZF użytego w kontekście jest zgodna z normą frazeologiczną (mimo iż tak nie jest), np. *ruski rok (9), *maczać w czymś ręce (6), *żal ściska dupe (7), *poprzewracało się komuś $w$ dupie (4), *nie wyściubiać skądś dzioba (2), *coś jest proste jak kilo sznurka w kieszeni; 2) zamiast oczekiwanego pierwowzoru podali inny frazeologizm, który jest do niego formalnie podobny, ale ma całkiem inne znaczenie, np. zagladać do kieszeni zamiast zagladać do kieliszka/butelki (1), wyciagać łapska po coś zamiast wyciagnąć nogi/kopyta (1); 3) w miejscu substytutu zamiast komponentu pierwowzoru podali człon innego frazeologizmu, który ma z pierwowzorem wspólne elementy semantyczne (na zasadzie kontaminacji), np. zamiast ZF żal/smutek/przeczucie itp. ściska komuś serce 'ktoś odczuwa wielki smutek, żal, ktoś ma bardzo mocne złe przeczucie' (SFPWN, s. 410) formy *żal ściska duszę (3) - por. np. coś uciska kamieniem dusze 'ciągła myśl o czymś nie dale komuś spokoju, coś obciąża czyjeś sumienie' (WSFPWNZP, s. 157), *żal ściska gardło (2) - por. np. serce podchodzi komuś do gardła 'ktoś doznaje silnych wzruszeń, przeżywa uczucie zachwytu, lęku, strachu, grozy itp.' (WSFPWNZP, s. 469); 4) potraktowali normatywny człon jako element kontekstu minimalnego, sugerując, że na jego miejscu może znaleźć się dowolny leksem: *Coś nie zajac, nie ucieknie (16) zamiast Praca/robota nie zajac, nie ucieknie. Omówienie ze studentami mechanizmów powstania ww. błędnych form frazeologicznych wspomoże uniknięcie podobnych nieporozumień w przyszłości.

Zadaniem respondentów, oprócz wskazania normatywnych form ZF, było również podanie definicji frazeologicznych pierwowzorów będących podstawą użyć innowacyjnych. Udzielone odpowiedzi są cennym materiałem do rozważań na temat udanego i nie bardzo udanego, a nawet błędnego definiowania ZF. Studenci w miarę sprawnie wymienili semy sygnifikacyjne, najbardziej ogólne, natomiast zdarzało im się pominąć w definicjach ważne semy denotacyjne i konotacyjne. Opis tego aspektu pracy z innowacjami wymieniającymi uważam za perspektywę badawczą.

Jak pokazuje doświadczenie, studenci polonistyki lwowskiej niechętnie posługują się frazeologizmami w mowie. Mimo starań lektorów, trudno zapamiętują i szybko zapominają te utrwalone połączenia wyrazowe, których ekwiwalenty nie są obecne w aktywnie używanym segmencie zasobu frazeologicznego języka ukraińskiego. Niemniej jednak frazeologii koniecznie należy uczyć zarówno na 
zajęciach z praktycznej polszczyzny, jak i w ramach niezależnego kursu, ponieważ rozwija ona nie tylko kompetencje językowe, ale również kulturowe. Wykorzystanie współczesnych tekstów literackich na zajęciach ze studentami uaktualnia proces glottodydaktyczny. Uczący się poznają frazeologię żywą, a zatem nie tylko konwencjonalną, lecz także tę spoza kodyfikowanej normy. Frazeologiczne innowacje wymieniające, jako jeden $\mathrm{z}$ najczęściej spotykanych rodzajów przekształceń strukturalno-semantycznych ZF w tekstach literackich, są cennym materiałem służącym pomocą przede wszystkim w uzmysłowieniu studentom złożoności znaczenia frazeologicznego, różnic pomiędzy frazeologizmem a wyrazem, zasad poprawnego posługiwania się utrwalonymi połączeniami wyrazowymi w warunkach dwujęzyczności i aktywnie rozwijającej się normy.

\section{SKRÓTY SŁOWNIKÓW I INNYCH ŹRÓDEŁ}

B - Stec D., 2007, Bingo, Wrocław.

BMN - Noszczyńska D., 2007, Blondynka moralnego niepokoju, Warszawa.

BW - Piątek T., 2006, Błogosławiony wiek, Wołowiec.

C - Karpowicz I., 2007, Cud, Wołowiec.

CW - Sowa I., 2002, Cierpkość wiśni, Warszawa.

CwN - Shuty S., 2002, Cukier w normie, Kraków.

DMC - Sowa I., 2006, 10 minut od centrum, Warszawa.

DP - Piątek T., 2005, Dobry Pan, Warszawa.

H - Piątek T., 2004, Heroina, Wołowiec.

HN - Noszczyńska D., 2008, Hormon nieszczęścia, Warszawa.

ISJP - Inny słownik języka polskiego. T. 1-2, 2000, M. Bańko (red.), Warszawa.

$\mathrm{Nh}$ - Karpowicz I., 2012, Niehalo, Wołowiec.

NKC - Karpowicz I., 2007, Nowy Kwiat Cesarza, Warszawa.

SiIP - Fabicka J., 2008, Seks i inne pryzkrości, Warszawa.

SFPWN - Stownik frazeologiczny PWN, 2005, A. Kłosińska (red.), Warszawa.

SŚM - Sowa I., 2002, Smak świeżych malin, Warszawa.

ŚT - Fabicka J., 2006, Świńskim truchtem, Warszawa.

TO - Fabicka J., 2006, Tango ortodonto, Warszawa.

WSFJP - Müldner-Nieckowski P., 2003, Wielki słownik frazeologiczny języka polskiego, Warszawa.

WSFPWNZP - Wielki słownik frazeologiczny PWN z przysłowiami, 2011, A. Kłosińska, E. Sobol (red.), Warszawa.

WSJP - Wielki słownik języka polskiego, P. Żmigrodzki (red.), https://www.wsjp.pl/ (dostęp: 18.09.2021).

\section{BIBLIOGRAFIA}

Bąba S., 2009, Frazeologia polska. Studia i szkice, Poznań.

Dilna J., 2008, Frazeologizmy w polskiej prozie młodzieżowej. Problemy z recepcja odbiorcy ukraińskiego uczacego się polszczyzny, w: W.T. Miodunka i A. Seretny (red.), W poszukiwaniu nowych rozwiąań. Dydaktyka języka polskiego jako obcego u progu XXI wieku. Kraków, s. $143-149$. 
Dilna J., 2011, Wspótczesny tekst literacki jako źródło polskiej frazeologii potocznej na zajęciach z języka polskiego jako obcego, ,Acta Universitatis Lodziensis. Kształcenie Polonistyczne Cudzoziemców. Teksty i podteksty w nauczaniu języka polskiego jako obcego - 3”, t. 18, Łódź, s. 129-134.

Dziamska-Lenart G., 2004, Innowacje frazeologiczne w powojennej felietonistyce polskiej, Poznań.

Horoz N., 2008, Transformaciï frazeologizmìv u tekstah sučasnih horvats'kih gazet: avtoref. dis. na zdobuttâ nauk. stupenâ kand. filol. nauk: spec. 10.02.03 „Slov 'âns'kì movi”, Kiïv.

Ignatowicz-Skowrońska J., 2008, Frazeologizmy jako tworzywo stylu współczesnej powieści polskiej, Szczecin.

Kravčuk A., 2005, Novij tip definicì frazeologizmiv u pol's'kih slovnikah, Problemi slov'âno ânoznavstva, Vip. 55, s. 181-196.

Krawczuk A., Nikołajczuk K., 2017, Frazeologia biblijna wieża Babel? O znajomości normatywnej frazeologii biblijnej z nomen proprium wśród native speakerów oraz Ukraińców uczących się polskiego, „Prace Językoznawcze” XIX/1, Olsztyn, s. 101-120.

Liberek J., 1998, Innowacje frazeologiczne w powojennej fraszce polskiej, Poznań.

Nikołajczuk K., 2013, Kompetencja rodzimych użytkowników polszczyzny oraz obcokrajowców (Ukraińców) w zakresie stosowania polskiej frazeologii temporalnej, „Acta Universitatis Lodziensis. Kształcenie Polonistyczne Cudzoziemców. Glottodydaktyka - media - komunikacja. Kształtowanie kompetencji komunikacyjnej”, t. 20, Łódź, s. 83-92.

Pajdzińska A., 1993, Frazeologizmy jako tworzywo współczesnej poezji, Lublin.

Sahata J., 2013, Świadomość normy frazeologicznej w zakresie zwiazków zawierających nazwy zwierzą (na przyktadzie ankiety przeprowadzonej wśród studentów polonistyki lwowskiej oraz uczelni polskich), w: A. Rabczuk (red.), Edukacja Międzykulturowa. Forum Glottodydaktyczne: Materiaty z Konferencji Naukowej. Warszawa, s. 129-145.

Stefanišin Û., 2016, Frazeologičnì innovaciï v sučasnìj pol's'kij prozì: avtoref. dis. na zdobuttâ nauk. stupenâ kand. filol. nauk: spec. 10.02.03 „Slov 'âns'kì movi”, L'vìv.

Teplâkov Ì., 2005, Frazeologična semantika (na materiali deâkih slov 'âns'kih mov), Problemi slov’ânoznavstva, Vip. 55, s. 156-163.

Tret'âkova I., 2011, Okkazional'naâ frazeologiâ (strukturno-semantičeskij i kommunikativno -pragmatičeskij aspekty): avtoref. dis. na soiskanie uč. stepeni d-ra filol. nauk: spec. 10.02.01 „Russkij âzyk”, Âroslavl'.

Julia Stefanyszyn

\section{FUNCTIONAL TYPES OF SUBSTITUTES IN THE STRUCTURE OF OCCASIONAL PHRASEOLOGICAL INNOVATIONS: INTERPRETATION WITH THE DIDACTIC ASPECT TAKEN INTO ACCOUNT}

Keywords: phraseological unit, phraseological norm, phraseological innovation, substitute, knowledge of phraseology, teaching phraseology

Summary. The article deals with comprehensive research into phraseological innovations based on replacement of one or several components of the phraseological unit in modern Polish prosaic texts (36 works by 10 Polish writers). Phraseological innovations were considered applying two approaches: structural-semantic and functional-pragmatic. Seven types of substitutes were outlined due to the functions they perform within the innovation. The impact of occasional substitution upon the meaning of the phraseological unit was assessed, taking into consideration its three aspects: significative, denotative and connotative. Possible ways of using texts containing innovations with substitutes during the language course and phraseology course with students of Polish philology at the Ivan Franko National University of Lviv were described. 